\title{
14 A (Post)Socialist Memory Space? East German and Mozambican Memories of Cooperation in Education
}

\section{Introduction}

In the socialist world, international contacts between national education systems usually developed in the context of bilateral agreements on cooperation and friendship. This was also the case for the People's Republic of Mozambique (PRM) and the German Democratic Republic (GDR). Nevertheless, in publications by contemporary actors, the starting point of East German and Mozambican cooperation in education is dated back to the years before Mozambican independence, when several GDR citizens began to work as teachers in underground schools run by the Mozambican liberation movement Frente de Libertação de Moçambique (FRELIMO) in the late 1960s. ${ }^{1}$ In historiographic representation on behalf of the GDR, this early cooperation in education during the liberation struggle against Portugal is depicted as the cornerstone for further cooperation between the two countries after Mozambican independence in $1975 .^{2}$ In the 1970s and 1980s a rapidly growing number of East German educational advisors and educators departed to Maputo, with the mission to contribute to the reconstruction of a postcolonial and socialist education system in Mozambique. ${ }^{3}$ Likewise, Mozambican students entered the GDR to continue their secondary education at the "School of Friendship" ${ }^{4}$ or to undergo vocational training, ${ }^{5}$ while

1 Herbert Graf, "Vor der Unabhängigkeitserklärung Mosambiks - Erinnerungen und Reflexionen," in Wir haben Spuren hinterlassen!, ed. Matthias Voß (Münster: Lit, 2005), 62. Hans-Jochen Roos, "Unterricht unter Palmen: Als Biologielehrer an der FRELIMO-Schule in Bagamoyo," in Wir haben Spuren hinterlassen!, ed. Matthias Voß (Münster: Lit, 2005).

2 For official self-representation see for instance Erich Honecker, Aus meinem Leben (Berlin: Dietz, 1981), 406. A similar argumentation can be traced in GDR documents with reference to Angola, see Immanuel Rafael Harisch, "Bartering Coffee, Cocoa and W50 Trucks: The Trade Relations of the GDR, Angola and São Tomé in a Comparative Perspective," Global Histories 3/2 (2017), 49, accessed November 7, 2019, doi:10.17169/GHSJ.2017.135.

3 Mathias Tullner, "Die Zusammenarbeit der DDR und Mosambiks auf dem Gebiet der Bildung und die Tätigkeit der Bildungsexperten der DDR in Mosambik," in Wir haben Spuren hinterlassen!, ed. Matthias Voß (Münster: Lit, 2005).

4 Lutz R. Reuter and Annette Scheunpflug, Die Schule der Freundschaft: Eine Fallstudie zur Bildungszusammenarbeit zwischen der DDR und Mosambik (Münster: Waxmann, 2006).

Ә OpenAccess. (C) 2021 Alexandra Piepiorka and Eduardo F. Buanaissa, published by De Gruyter. (c) BY This work is licensed under the Creative Commons Attribution 4.0 International License. https://doi.org/10.1515/9783110623543-014 
other young Mozambicans merely hoped to receive vocational education in the framework of contract labor in East German enterprises. ${ }^{6}$

Although Mozambican and East German educational trajectories differed quite remarkably, the common experience to work through a foreign and socialist education system offers space for some geteilte Erinnerungen ("shared experiences") $)^{7}$ from protagonists on both sides. In this context we assume the possibility of a small-scale Afro-European "memory space," ${ }^{8}$ which would presumably lie in between the GDR and Mozambique, nestled in the common educational history of both. This memory space may seem relatively small, but nevertheless bears the potential of having conserved rich memories of the PRM and the GDR two formerly socialist (education) systems, whose place in the overall memory culture in the respective countries is still being negotiated. Complementary to the overarching national debates, this article focuses on the written and personal memories of protagonists, who were engaged in cross-border educational endeavors and encounters between the PRM and the GDR. In search of such memories, we consulted publications that can be combined under the label of "memory literature." ${ }^{9}$ Our analysis aims at catching a glimpse of (post)socialist worlds

5 Ilona Schleicher, "Berufsbildung und Wirtschaftsbeziehungen DDR - Mosambik," in Engagiert für Afrika: Die DDR und Afrika II, ed. Ulrich van der Heyden (Münster: Lit, 1994).

6 Ulrich van der Heyden, Wolfgang Semmler and Ralf Straßburg, Mosambikanische Vertragsarbeiter in der DDR-Wirtschaft: Hintergrund - Verlauf - Folgen (Münster: Lit, 2014); Marcia C. Schenck, "From Luanda and Maputo to Berlin: Uncovering Angolan and Mozambican migrants' motives to move to the German Democratic Republic (1979-1990)," African Economic History 44 (2016).

7 The German term geteilte Erinnerung has a double meaning, containing a notion of shared and divided memory at the same time.

8 For the concept of memory spaces see Aleida Assmann, Erinnerungsräume: Formen und Wandlungen des kulturellen Gedächtnisses (Munich: C. H. Beck, 1999).

9 Memory literature does encompass a variety of written sources, reaching from historically inspired and sometimes bestselling novels to self-published memoirs and autobiographical stories. In literature studies especially, but also in interdisciplinary research dealing with collective memory, researchers seem to favor historical novels as objects of analysis. However, for our analysis we selected autobiographically inspired books written by amateur authors and contemporary witnesses from the former GDR and Mozambique, that offer personal views on the socialist past in the respectively other country. For a discussion of German memory literature see Aleida Assmann, "Wem gehört Geschichte? Fakten und Fiktion in der neueren deutschen Erinnerungsliteratur,” Internationales Archiv für Sozialgeschichte der deutschen Literatur 36 (2011). See also Friederike Eigler, Gedächtnis und Geschichte in Generationenromanen seit der Wende (Berlin: Erich Schmidt Verlag, 2005). For Mozambican memory literature see Ana Margarida Fonseca, "(Re)Configurations of Identity: Memory and Creation in the Narrative of Mia Couto," in Mozambique on the Move: Challenges and Reflections, ed. Sheila Pereira Khan, Maria Paula Meneses, and Bjørn Enge Bertelsen (Leiden and Boston: Brill, 2018). Also consult 
of memory, which might have emerged in the context of GDR-Mozambican cooperation in education. Our argument is that a collective memory concerned with state socialism does exist separately in both formerly socialist states. At the same time, personal memory of certain East Germans and Mozambicans transverse these national memory horizons by offering common as well as differing memories of the socialist past of both countries - resulting in a multiplicity of (post)socialist memory spaces. Accordingly, Millei et al. refer to "(post)socialist spaces" in the plural to "highlight this complexity of the time-spaces of historical socialism and what followed."10

In the following, we first discuss the role of memory literature in the context of post-socialist and cross-national remembering processes. Secondly, we summarize memory debates on the socialist phase in reunited Germany and in post-socialist Mozambique. Thirdly, we present our interpretation of post-socialist memory literature, and finally we discuss the post-socialist memory space in between East Germany and Mozambique.

\section{Theoretical Considerations on Post-socialist Memory Making}

As a starting point, we want to raise the question whether or not memories of Mozambican and East German expatriates do play a part in (a) post-socialist "memory space" of both countries. ${ }^{11}$ Picking up this point, we started wondering about the role of memory literature in the overall memory making in post-socialist spaces like East Germany and Mozambique. In Assmann's considerations, memory literature constitutes a genre that combines personal experience, historic events, and elements of fiction into a literary text and eventually works out historical perspectives that hitherto did not make it into the collective memory of a given society. ${ }^{12}$ Consequently, memory literature appears to offer a space for subliminal memories, situated somewhere in between the canonized cultural

Maria do Carmo Ferraz Tedesco, "Reconfiguração da Moçambicanidade nos romances de Mia Couto e Paulina Chiziane," Revista Mosaico 3 (2010). For the role of testimony books in Mozambican memory discourse see João Paulo Borges Coelho, "Politics and Contemporary History in Mozambique: A Set of Epistemological Notes,” Kronos 39 (2013), 29.

10 Zsuzsa Millei, Iveta Silova, and Susanne Gannon, “Thinking Through Memories of Childhood in (Post)Socialist Spaces: Ordinary Lives in Extraordinary Times,” in Children's Geographies, published online, August 1, 2019, doi:10.1080/14733285.2019.1648759.

11 Assmann, Erinnerungsräume.

12 Assmann, "Wem gehört Geschichte," 216-217. 
memory of a given society and the inter-generational communicative memory of certain groups within this society. ${ }^{13}$ As memory literature may deliberately integrate autobiographical and fictional features into the storyline, such texts are less reliable in terms of historical accuracy. ${ }^{14}$ However, she states that memory literature offers a platform for a wide range of little stories that reflect the bigger history, but which remained previously untold and unheard and are not part of the official narrative. ${ }^{15}$ In line with Assmann's ideas, we consider memory literature as a valuable non-academic and personal contribution to collective memory making on socialist times in both Germany and Mozambique. ${ }^{16}$

As the memories under examination emerged in at least two national contexts and were (re)told by de facto migrants, ${ }^{17}$ we would like to address spatiality here. To our understanding, Assmann's notion of “memory spaces" refers to (subjective or collective) memories of specific places, and to (inanimate) spaces of remembrance like historical monuments, that transcend personal memory. ${ }^{18}$ This understanding of space in memory processes builds upon the concept of lieux de mémoire (translated to "realms of memory") as introduced by Pierre Nora. Nora and colleagues started to explore French history and collective identity through a constructivist analysis of concrete memory sites, like the Eiffel

13 For the different forms of individual and collective memory see Aleida Assmann, "Memory, Individual and Collective," in The Oxford Handbook of Contextual Political Analysis, ed. Robert E. Goodin and Charles Tilly (Oxford: Oxford University Press, 2006), 210-224. Also see Harald Welzer, Das kommunikative Gedächtnis: Eine Theorie der Erinnerung (Munich: C. H. Beck, 2002). 14 Assmann, "Memory, Individual and Collective," 223. According to Assmann, in memory literature a generous portion of "fiction" is added into the overall storyline - e.g. events are described rather from an aesthetic point of view, but with no reference to time or place; or fictional characters are added into the plot to make the text more consistent and to synthesize past events for the reader. Even though fiction or selective remembering often triumph over "accuracy" in historical novels and autobiographical memoires, such literary products still serve as valuable sources for understanding past events or past emotions.

15 Assmann, "Memory, Individual and Collective," 222.

16 Assmann discusses the function of collective memory as a unifying framework for groups or nations with reference to Maurice Halbwachs and Pierre Nora. But she also reflects on the potential of latent and "dysfunctional memories" that may eventually delegitimize, correct or complement the official memory framework; see Assmann, Erinnerungsräume, 131-142. In a way, memory literature and autobiographical testimonies may serve as corresponding supplements to official memory making. Also consult Maurice Halbwachs, Das kollektive Gedächtnis (Stuttgart: Enke, 1967).

17 For migrant memory see an overview by Julia Creet, "Introduction: The Migration of Memory and Memories of Migration," in Memory and Migration: Multidisciplinary Approaches to Memory Studies, ed. Julia Creet and Andreas Kitzmann (Toronto: University of Toronto Press, 2011).

18 Assmann, Erinnerungsräume. 
tower, but also through immaterial sites, like symbols or social divisions within the country. ${ }^{19}$ Although these lieux were highly relevant for France's national identity, Nora's initial selection was critiqued for overlooking transnational aspects of French identity, such as lieux connected to France's inglorious colonial past. ${ }^{20}$ Nevertheless, Nora's concept proved useful for similar projects in other European countries. ${ }^{21}$ In addition to such national adaptations, Nora's concept of lieux fostered an international discussion on the possibility of collective memory making beyond the "national container" as a spatial unit. ${ }^{22}$ Over the years, scholars have reworked Assmann's “memory spaces” and Nora's lieux de mémoire by applying their concepts to the transnational level. ${ }^{23}$

But how can one capture rather immaterial memory landscapes on socialist pasts that seem entangled in-between two countries (and continents)? For our purpose, we found the concept of "travelling memory" 24 and the corresponding discussion about transnationality in the field of memory studies helpful. ${ }^{25}$ Within this framework memories rather emerge from cross-border movement of people and media ${ }^{26}$ then from circumscribed places or national boundaries. ${ }^{27}$ As we

19 Pierre Nora and Lawrence D. Kritzmann, Realms of Memory: Rethinking the French Past, Vol. 1-3 (New York: Columbia University Press, 1996-1998).

20 Etienne Achille, Charles Forsdick, Lydie Moudileno, Postcolonial Realms of Memory: Sites and Symbols in Modern France (Liverpool: Liverpool University Press, 2020). This critique is especially true to Nora's publications on the French republic and nation, whereas the later volumes on "Les Frances" did also explore the historical role of migrants or religious minorities within French society. See relevant chapters in Nora and Kritzmann, Realms of Memory.

21 For Germany see Etienne François and Hagen Schulze, Deutsche Erinnerungsorte - Eine Auswahl (Munich: C. H. Beck, 2005). Martin Sabrow, Erinnerungsorte der DDR (Munich: C. H. Beck, 2009).

22 See Indra Sengupta, "Introduction. Locating lieux de mémoire: A (Post)colonial Perspective," in Memory, History, and Colonialism: Engaging with Pierre Nora in Colonial and Postcolonial Contexts, ed. Indra Sengupta (London: German Historical Institute, 2009). Hans Henning Hahn, Robert Traba, and Peter Oliver Lowe, Deutsch-Polnische Erinnerungsorte, Vol. 1-5 (Paderborn: Schöningh, 2012-2015).

23 Pim den Boer, Europäische Erinnerungsorte, Volume 3: Europa und die Welt (Munich: Oldenbourg, 2012); Ulrike Schmieder, “Orte des Erinnerns und Vergessens: Denkmäler, Museen und historische Schauplätze von Sklaverei und Sklavenhandel,” in Comparativ 22 (2012).

24 Astrid Erll, “Travelling Memory,” Parallax 17 (2011).

25 Chiara De Cesari and Ann Rigney, Transnational Memory: Circulation, Articulation, Scales (Berlin: De Gruyter, 2014); Astrid Erll, Kollektives Gedächtnis und Erinnerungskulturen: Eine Einführung, third edition (Stuttgart: J.B. Metzler, 2017), 123-126.

26 An impressive example of travelling memory items may be found in East German media products, like popular music or video cassettes that were brought to Maputo suburbs by Mozambican worker-trainees returning from the GDR. The long-lasting impact of this group of returnees and their souvenirs on urban culture in Maputo is documented in this volume (see Fernando 
navigate within the context of global socialism and analyze written testimonies on binational exchanges in education, we find the perspective of travelling memories intriguing. Although plots connected to transnational identity building are highlighted in this strand of research, researchers rarely focus on the transnational, socialist experience in memory literature. ${ }^{28}$ A remarkable contribution is the study of Gronenthal, who dived into a world of nostalgia in East German and Polish literature and worked out post-socialist nostalgia as a transnational phenomenon. ${ }^{29}$ Furthermore, there is an interdisciplinary interest in what was labeled "Eastalgia" 30 or "post-communist nostalgia"31 within memory literature, but many contributions stay focused on the European memory space. ${ }^{32}$ So, how to examine the Afro-European experience of remembering socialism?

Agostinho Machava). See also Malte Wandel, Einheit, Arbeit, Wachsamkeit: Die DDR in Mosambik (Heidelberg, Berlin: Kehrer Verlag: 2012).

27 Erll, Kollektives Gedächtnis, 126.

28 Transnationality in memory literature is usually discussed with reference to diaspora and the experience of loss, as well as (forced) migration or collective trauma. For transnational melancholy see for instance Stephanie Siewert, "Die Topographie der Melancholie in transnationaler Perspektive," in Raum und Gefühl: Der Spatial Turn und die neue Emotionsforschung, ed. Gertrud Lehnert (Bielefeld: Transcript, 2011). For a discussion of transnational memory in the context of diaspora and migration, see the edited volume by De Cesari and Rigney, Transnational Memory. For collective trauma in memory literature consult Anja Tippner and Anna Artwińska, Narrative of Annihilation, Confinement, and Survival: Camp Literature in a Transnational Perspective (Berlin: De Gruyter, 2019).

29 Mariell C. Gronenthal, Nostalgie und Sozialismus: Emotionale Erinnerung in der deutschen und polnischen Gegenwartsliteratur (Bielefeld: Transcript, 2018).

30 Thomas Kunze and Thomas Vogel, Ostalgie international: Erinnerungen an die DDR von Nicaragua bis Vietnam (Berlin: Ch. Links, 2010); Marcia C. Schenck, "A Chronology of Nostalgia: Memories of Former Angolan and Mozambican Worker Trainees to East Germany," in Labor History 59 (2018), doi:10.1080/0023656X.2018.1429187.

31 Maria Todorova and Zsuzsa Gille, Post-Communist Nostalgia (Oxford: Berghahn 2010). See also Enzo Traverso, Left-Wing Melancholia: Marxism, History, and Memory (New York: Columbia University Press, 2016).

32 Nevertheless, there is a strand of research on memories of foreign students in the former GDR; for instance, for Cuban students consult relevant chapters in Wolf-Dieter Vogel and Verona Wunderlich, Abenteuer DDR: Kubanerinnen und Kubaner im deutschen Sozialismus (Berlin: Karl Dietz, 2011); Susanne Ritschel, Kubanische Studierende in der DDR: Ambivalentes Erinnern zwischen Zeitzeuge und Archiv (Hildesheim: Georg Olms, 2015). For Latin American students in the Soviet Union see Tobias Rupprecht, Soviet Internationalism After Stalin: Interaction and Exchange Between the USSR and Latin America During the Cold War (Cambridge: Cambridge University Press, 2015), 191-229. 
In this regard we find the discussion connected to "post-socialism" in educational science inspiring, ${ }^{33}$ because the authors do not stay within the European framework, but decisively transverse the global scale when researching socialist experiences of schooling, education, and childhood from all over the world. ${ }^{34}$ The authors approach the socialist past through personal memories and contrast these memories with official narratives on childhood in socialist states, as well as evaluations on this past in scientific and public discourses. During their analysis, the researchers seek to "think with" memories while "thinking through" childhood and the everyday life in socialist education systems. In that framework, they give attention to collective negotiation processes of that socialist past in the post-socialist space and also examine their own role in such processes - both as memory holders and as scientists engaged in the generation of knowledge about the socialist past. ${ }^{35}$ Before moving to our analysis of individual memories by formerly educational travelers, we wish to briefly explore the course of collective remembering in both post-socialist societies. For that purpose, we will dive into public debates on the socialist past in post-socialist Germany and Mozambique and compare remembrance in both local contexts.

33 Iveta Silova, Post-Socialism Is Not Dead: (Re)Reading the Global in Comparative Education (Bingley: Emerald Group Publishing, 2010); Iveta Silova et al.,, Reimagining Utopias: Theory and Method for Educational Research in Post-Socialist Contexts (Rotterdam: Sense Publishers, 2017).

34 Iveta Silova, Nelli Piattoeva, and Zsuzsa Millei, Childhood and Schooling in (Post)Socialist Societies: Memories of Everyday Life (Cham: Springer International Publishing, 2018).

35 Millei, Silova, and Gannon, "Thinking Through," 3. We fit into the category of researches born in socialist systems (Poland and Mozambique), and to a certain extent we share the experience of childhood in socialism with the authors cited above. At the same time, we share this experience with the authors of the memory books we use for our analysis of cross-national remembering of socialism. Therefore, we agree with Millei et al. that writing about a socialist past that - in bits and pieces - seems related to one's own biography can be a methodologically challenging venture, especially were "collective biography collapses the binary that separates the knowledge generating expert from the layperson remembering.” Ibid. 


\section{Remembering Socialism in Post-socialist Germany and Mozambique}

In German and Central European memory debates, state socialism is considered a significant period for contemporary historiography. ${ }^{36}$ Historians conducted research on state socialism from the 1990s onwards and results on socialist education in the former GDR were gradually woven into the overall German memory discourse. Studies on socialist education in the GDR examined political indoctrination in schools and mechanisms of sanction within the education system, among other rather unpleasant topics. ${ }^{37}$ These negative aspects of GRD education were discussed publicly and received a prominent place in the collective memory making in unified Germany. ${ }^{38}$

Nevertheless, the collective memory on the former GDR lived through considerable inner-German controversies in the post-1990s era and, interestingly enough, it remains a contested memory space up-to-date. ${ }^{39}$ What lies at the core of such controversies? The German historian Martin Sabrow sums up that at least three narratives are concurring for hegemony in GDR historiography. The first focuses on totalitarianism and the malice of dictatorship (official mem-

36 Martin Sabrow, "Zeitgeschichte als Aufarbeitung: Der Fall DDR," in Aufarbeitung der Aufarbeitung: Die DDR im geschichtskulturellen Diskurs, ed. Saskia Handro (Schwalbach: Wochenschau-Verlag, 2011), 23.

37 Gert Geissler and Ulrich Wiegmann, Schule und Erziehung in der DDR: Studien und Dokumente (Neuwied: Hermann Luchterhand, 1995); Tilman Grammes, Henning Schluß, and HansJoachim Vogler, Staatsbürgerkunde in der DDR: Ein Dokumentenband (Wiesbaden: VS Verlag, 2006); Andreas Gratzemann, Die Erziehung zum "neuen” Menschen im Jugendwerkhof Torgau: Ein Beitrag zum kulturellen Gedächtnis (Berlin: Lit, 2008).

38 Gronenthal, Nostalgie und Sozialismus, 38-41. Official GDR memorial sites, for instance, were placed in former special status prisons of the Ministry for State Security (MfS or Stasi), a "Berlin Wall" museum opened up in 1998, and former Stasi headquarters were turned into museums in Leipzig and Berlin. See Carola S. Rudnick, Die andere Hälfte der Erinnerung: Die DDR in der deutschen Geschichtspolitik nach 1989 (Bielefeld: Transcript, 2011). A wider variety of memory perspectives was adapted in cinematographic productions on the GDR, which would address topics like persecution or monotony in state socialism, but also encompass comedic elements and Eastalgia; see Gerhard J. Lüdeker, Kollektive Erinnerung und nationale Identität: Nationalsozialismus, DDR und Wiedervereinigung im deutschen Spielfilm nach 1989 (Munich: Ed. Text + Kritik, 2012), 206-272. On representations of everyday life in GDR museums see Regina Göschl, DDR-Alltag im Museum: Geschichtskulturelle Diskurse, Funktionen und Fallbeispiele im vereinigten Deutschland (Münster: Lit, 2019).

39 Sebastian Klinge, 1989 und wir: Geschichtspolitik und Erinnerungskultur nach dem Mauerfall (Bielefeld: Transcript, 2015). 
ory politics), the second praises the fruits of socialist progress (former GDR functionaries and supporters of the system), and the third paints a picture of adjustment and "coming to terms" with the GDR system ("Arrangementgedächtnis" of average GDR citizens). ${ }^{40}$ Although in 1998 the Federal Foundation for the Reappraisal of the SED Dictatorship was initiated to deal with the various aspects of life in the GDR and a common German memory discourse, ${ }^{41}$ critics observe that in public debate the SED state's surveillance apparatus and the one-party dictatorship of the SED prevailed as a major topic. With this emphasis, public attention was rightly paid to the victims of the SED state, but the memory horizon of a probably large majority of GDR citizens was disregarded. Many of the less spectacular tales on everyday life in the GDR ended up being less visible in the collective memory of unified Germany, but stayed conserved in the communicative memory of East Germans. This may be exemplified by the diverging perceptions of GDR history as expressed by school pupils from East and West. ${ }^{42}$ West German pupils tend to associate the GDR with repression, as told in school, and horrifying stories about "passing the inner-German border," as told by Western family members. East German pupils, on the other hand, rather blend personal "reminiscences of original history" and local patriotism into the historical narrative, while they tend to trivialize the context of the dictatorship. ${ }^{43}$ Such memory disparities point towards a still ongoing process of German re-unification and identity building, in which memory making does play a prominent part. Accordingly, the memory discourse on the socialist past of Eastern Germany continues to be a worthwhile research agenda in unified Germany. ${ }^{44}$

40 Sabrow, “Zeitgeschichte als Aufarbeitung," 28-29.

41 For further information see https://www.bundesstiftung-aufarbeitung.de/.

42 The corresponding study was based on more than 200 interviews with school pupils from Lower Saxony, as well as Western and Eastern Berlin; see Sabine Moller, "Diktatur im Familiengedächtnis: Anmerkungen zu Widersprüchen im Geschichtsbewusstsein von Schülern," in $A u$ farbeitung der Aufarbeitung: Die DDR im geschichtskulturellen Diskurs, ed. Saskia Handro (Schwalbach: Wochenschau-Verlag, 2011), 140-141.

43 Moller, "Diktatur," 149.

44 This agenda may be exemplified by studies on the emergence and maintaining of East German identities even after 1990 and its representation in memory literature; for instance see Bernd Blaschke, "Erzählte Gefühle und Emotionen des Erinnerns: Ostdeutsche Identitätsliteratur der in den 1960er und 1970er Jahren Geborenen," in Ostdeutsche Erinnerungsdiskurse nach 1989: Narrative kultureller Identität, ed. Elisa Goudin-Steinmann and Carola Hähnel-Mesnard (Berlin: Frank \& Timme, 2013). See also Regine Criser, "Zwischen Anpassung und Instrumentalisierung: Hybride Lebensnarrative in der Literatur nach 1989," in ibid. For an overview of GDRrelated research, see Ulrich Mählert, Die DDR als Chance: Neue Perspektive auf ein altes Thema (Berlin: Metropol, 2016). 
In the case of Mozambique, colonialism and the post-independence transition to state socialism have an outstanding relevance for the country's history and, accordingly, also its educational development. Still it seems that state socialism as a postcolonial development phase (around 1975-1990) tends to be overlooked in current memorial debates and in research on Mozambican history of education. ${ }^{45}$ Instead, remembering the struggle for independence and an education system in the FRELIMO-run "liberated zones" during the 1960s are points of interest in the country's current politics of remembrance. ${ }^{46}$ Thus, expectations on how to deal with the socialist past are quite different in post-socialist Mozambique and Germany.

The prerogative of interpreting the Mozambican past until today remained with FRELIMO. Since independence, FRELIMO continues to exercise control over the "mechanisms of engaging with the past and writing the national narrative of the war" as ruling party. ${ }^{47}$ This would also include muzzling unwanted memories. However, sporadic explosions of remembrance in public debates accompany FRELIMO's channeled politics of forgetting. For example, the former warring factions FRELIMO and RENAMO would maintain general silence on the civil war on most occasions, and thereby follow the "the imperative for attaining peace and political stability." ${ }^{48}$ Still, both parties occasionally use public memory debates to reinvigorate old rivalries with their former war opponents. Election campaigns are used to accuse the other side of respective war crimes, and regular "interruptions of silence" in the Mozambican parliament occur during these periods..$^{49}$ But outside of the public space, an unspoken silence agree-

45 Many Mozambican and international publications on the socialist period came out during exactly that time and were marked by "sentiments of solidarity and sympathy;" see Michael Cross, An Unfulfilled Promise: Transforming Schools in Mozambique (Addis Ababa: OSSREA 2011), 12. More recent publications discuss education during state socialism on few pages only, e.g. Mouzinho Mário et al., Higher Eduaction in Mozambique: A Case Study (Oxford: James Currey, Maputo: Imprensa \& Livraria Universitária UEM, 2003), 7-10. Also Patricio Vitorino Langa, Higher Education in Portuguese Speaking African Countries: A Five Country Baseline Study (Cape Town: African Minds 2013), 63, accessed January 5, 2020, www.africanminds.co. za/wp-content/uploads/2014/02/AM-HE-in-Lusophone-Africa-Text-and-Cover-web.pdf.

46 See for instance Salvador André Zawangoni, A FRELIMO e a Formação do Homem Novo (1964-1974 e 1975-1982) (Maputo: CIEDIMA, 2007); Joel das Neves Tembe, História da Luta de Libertação Nacional (Maputo: Ministério dos Combatentes, Direcção Nacional de História, 2014). The corresponding "liberation script" in public memory debates was analyzed in Coelho, "Politics," 21.

47 Victor Igreja, "Memories as Weapons: The Politics of Peace and Silence in Post-Civil War Mozambique," Journal of Southern African Studies 34 (2008): 544.

48 Igreja, "Memories as Weapons," 540.

49 Ibid, 545-550. 
ment seems to prevail, as explained by a parliamentary deputy of RENAMO: "the people that insult one another in the parliament, when they meet in a barraca [a hut where alcohol is sold] they don't talk about the bad things of the past."50

Did the educational history marked by socialism in Mozambique fall into oblivion, because the same time period was overshadowed by civil war, or was it simply no longer important? It seems that FRELIMO nowadays has little interest to dwell on memories of the socialist past. ${ }^{51}$ Although street names such as Karl Marx Avenue or Mao Tse Tung Avenue shape Maputo's urban landscape and are clear reminders of the socialist past, this same past seems to have no positive or negative place in official memory. ${ }^{52}$ Pitcher considers in this regard that "[w]ith the implementation of structural adjustment in 1987 and major constitutional changes since 1990, the government has dropped most reference to socialism." 53 At the same time, the scientific interpretation of Mozambique's socialist phase seems to move within "narratives of triumph and failure" 54 : while post-independence literature tended to glorify the socialist development, the same phase was generally declared as failure in writings after the system change. Contrary to both extremes, Pitcher demands that "scholars need to come to terms with the socialist period in Mozambique" 55 and eventually move away from both antithetical interpretations.

50 Ibid, 551. Such attempts to break the collective amnesia have been the subject of academic debates in Mozambique, for instance, in the "Philosophical Ateliers" organized by the prominent Mozambican philosopher Severino Ngoenha. These ateliers take place in the "Garden of the Madgermanes" (a term referring to the former Mozambican workers returned from the GDR in Maputo; see Machava, this volume). In this context, discussions have often been associated with the theme of revisiting the past to construct national reconciliation and to activate citizenship. Meetings are announced via social media channels like Facebook in a group named “Atelier Filosófico"; see group content on Facebook Inc., accessed July 26, 2020, https://www. facebook.com/Atelier-Filos\%C3\%B3fico-2217100891889370/.

51 Igreja, "Memories as Weapons," 554; Anne M. Pitcher, "Forgetting from Above and Memory from Below: Strategies of Legitimation and Struggle in Postsocialist Mozambique," Journal of the International African Institute 76 (2006).

52 Igreja, "Memories as Weapons," 545.

53 Pitcher, "Forgetting from Above," 95.

54 Pitcher, "Forgetting from Above," 106.

55 Pitcher, "Forgetting from Above," 106. 


\section{Remembering Each Other: Mozambican Memory and "Remembering Mozambique" in (East) German Memory Literature}

After briefly recapitalizing the collective memory making on the socialist era in both countries, we would like to focus on the personal memories of Mozambicans and East Germans about each other. From the preceding section we conclude that neither Mozambique plays a central role in German historiography, nor does East Germany appear to be central to Mozambican memory debates. Nevertheless, we found pieces of common memories of socialist times in German as well as Mozambican memory literature. Such memories were recollected by East Germans and published with a focus on "remembering Mozambique" and the authors' mission in Africa, as well as by Mozambicans who published personal testimonies about their lives in the GDR. ${ }^{56}$

Although the chosen memory sources are written from the perspective of temporary migrants and therefore "outsiders" to the given society, they may be of complementary relevance for each other, for at least two reasons. First, we would maintain that memory literature published by Mozambicans contributes to include non-German perspectives into memory spaces connected to the GDR. ${ }^{57}$ Remarkably enough, non-German remembering of the GDR occasionally results to be rather benevolent when compared to the inner-German debates. ${ }^{58}$ From time to time even a breeze of nostalgia seems to fly through Mozambican memories of the GDR. ${ }^{59}$ The bitter sweetness of remembering an adolescence as worker trainees in East Germany can be traced by the rousing stories of Mozambican returnees popularly known as "Madjermanes." ${ }^{60}$ Second, we hold that selected East German memory books preserved a wide range of memories of the People's Republic of Mozambique. Associated memories of socialist Mozambi-

56 All consulted memory sources are listed in the bibliography section.

57 For further reading on non-German perspectives consult Kunze and Vogel, Ostalgie international.

58 West-German novelists, for instance, tend to present a "negative portrayal of the GDR." Stuart Parkes, "Literary Portrayals of the GDR by Non-GDR citizens," in The GDR Remembered: Representations of the East German State Since 1989, ed. Nick Hodgin and Caroline Pearce (Camden House: Boydell \& Brewer, 2011), 66.

59 Tanja Müller, Legacies of Socialist Solidarity: East-Germany in Mozambique (London: Lexington, 2014); Marcia C. Schenck, "Ostalgie in Mosambik: Erinnerungen ehemaliger mosambikanischer Vertragsarbeiter in der DDR,” Südlink 172 (2015).

60 See contributions of Machava, and Alberto and Schenck, this volume. 
que mostly emerged in the context of East German working visits. Such visits were rather rare and only designated GDR citizens were allowed to travel to foreign countries in the 1970s and 1980s. ${ }^{61}$ The same is true for most Mozambican citizens at that time. It seems though that especially that exceptionality of AfroEuropean contacts between nominally socialist partners contributed to the intensity of emotional memories on such encounters. ${ }^{62}$ In this regard, we found the cooperation in education between the GDR and PRM to be a productive ground for recollecting common as well as unique memories of such encounters. What we found were memories of former colleagues, teachers or students, memories of educational institutions, memories of pedagogic settings, and, most remarkably, of the everyday life in a socialist world - a world that for both Mozambican and East German memory bearers disappeared in the early 1990 s.

\section{Interpretation of Memory Literature and Memories of Cooperation in Education}

While reviewing the available memory literature by Mozambicans on socialist Germany and by East Germans on socialist Mozambique, it became apparent that publications connected to educational cooperation are few in number, but still rich in content. ${ }^{63}$ The following section is devoted to the multifold memories of everyday life in both countries as represented in published memoires of former expatriates or students in their respective professional and private settings. ${ }^{64}$

61 Jens Niederhut, Die Reisekader: Auswahl und Disziplinierung einer privilegierten Minderheit in der DDR (Leipzig: Evangelische Verlagsanstalt, 2005).

62 Gertrud Lehnert, "Raum und Gefühl," in Raum und Gefühl: Der Spatial Turn und die neue Emotionsforschung, ed. Gertrud Lehnert (Bielefeld: Transcript, 2011).

63 Further memory literature by international educators who have worked in Mozambique during the 1970s and 1980s is available in English: Chris Searle, We're Building the New School: Diary of a Teacher in Mozambique (London: Zed Press, 1981); John S. Saul, Revolutionary Traveller: Freeze-Frames from a Life (Winnipeg: Arbeiter Ring Publishing, 2009).

64 Following our research interest, we identified 16 publications referring to contexts of educational exchange between the GDR and Mozambique. From that data corpus, we chose five memory books and five articles from edited volumes for in-depth analysis and used them as textual framework for carving out traces of common memory on both countries. Although almost all texts were published in German, four narrators are of Mozambican origin. To counterbalance this perspectival distortion in favor of written testimonies in the German language, we would like to recommend the relevant chapters in this volume that primarily rely on oral history sources from former Mozambican worker trainees and were actually conducted in Portuguese (see Machava; Alberto and Schenck, this volume). 


\section{Packing Bags and Imagining "the Other"}

To begin with, it is worth mentioning that both Mozambican and East German memory texts extensively comment on the other society from the perspective of a guest or migrant. The first impressions upon arrival were relatively dominant for the perception of the other country. But the phase before arrival is also often described, because authors started to imagine the country of destination in their home country already. Especially in the arrival context, authors realized that they had eventually deemed themselves somewhat closer to paradise then reality in the host country would allow. Although the term paradise seems a bit exaggerated, we read that for both Mozambicans and East Germans the respective other country offered a notion of paradise-or at least of adventure and escape-in the phase before their arrival. Nevertheless, there was a slightly different emphasis on what paradise might mean for East Germans compared to Mozambicans. We will elaborate on these nuances of paradise-or Promised Landwhile following the memories of Frank and Ibraimo. The GDR citizen Frank is the protagonist of a German memory fiction book. ${ }^{65}$ Mozambican-born Ibraimo is the author of his own autobiography. ${ }^{66}$ While Frank travelled southwards to work as educational advisor for the Mozambican government and being a professionally experienced adult ${ }^{67}$ the young man Ibraimo traveled northwards to pursue further education, but found himself as a contract worker in the GDR.

65 The novel's author himself has worked in Mozambique in the education sector; Helmut Dora, Kokos und bitterer Tee: Tage und Nächte in Mosambik (Rostock: BS-Verlag, 2009). We categorized this novel as a memory fiction book, because it combines elements of Mr. Dora's autobiographical experience of working in Mozambique with fictional elements, like the use of alter egos for the characters in the book. The use of alter egos certainly was meant to protect his former colleagues' identities and their private life, but also gave the author more freedom for interpreting his own past - with all its delicate details, like a love affair or other drama. The novel's protagonist, for instance, was renamed to "Frank", but the main storyline of the books is actually built around Mr. Dora's own experience in Mozambique. We were able to reconstruct this insight, because Mr. Dora was willing to recall parts of his life story to one of the authors during an interview in 2014.

66 Ibraimo Alberto, Ich wollte leben wie die Götter: Was in Deutschland aus meinen afrikanischen Träumen wurde (Köln: Kiepenheuer \& Witsch, 2014).

67 We were shocked to discover that Dora uses the n-word in his book. It seems that the author uses the racist terminology more often when it comes to the description of people from rural Mozambique. This selectivity is worth noticing, because then the racialized imagery not only encompasses a black and white dualism, but also employs categories like rural and urban, educated and uneducated, or colleague and stranger, when it comes to racist terminology. Nevertheless, in at least one story he refers to a colleague and friend of his as "the strong $\mathrm{n}^{\star \star \star \star}$." Dora, Kokos, 69. Having this in mind, one could argue that title and subtitle also refer to 
For Frank, like for most East Germans at that time, working in Mozambique offered the opportunity to work and travel abroad, which was a great privilege at a time when cross-border movement was strongly regulated or even impossible for most GRD citizens. The East German imaginary world of faraway lands can be exemplified by the daydreaming of Frank. Although Frank was not sure where to locate Mozambique on a globe, his thoughts started traveling there as soon as the employment offer was announced to him by a GDR ministry. ${ }^{68}$ His daydreaming was harshly criticized by his wife Rita:

Well. So, you have already accepted the job? [...] Without even knowing anything about this country, your thoughts are already there. We have our kids here. What should we do with them? [...] Maybe there is racism, or maybe people are shooting there. Probably it's also very hot. We know nothing - and then, such adventures! ${ }^{69}$

Yet, despite her concerns about their children, her discomfort to leave her "interesting job," and the worries concerning the overall situation in Mozambique, she decides to join Frank on his mission, as she did years before when both migrated to Cuba. ${ }^{70}$ Both protagonists mention their sense of solidarity as an important motive to participate in Mozambique's post-socialist reconstruction, meaning the idea of building a socialist utopia abroad may also have played a part in their vision of faraway Mozambique.

A similar adventure spirit may be observed in the storyline of young Mozambicans, who preponderantly were not able to travel to Europe due to economic stratification in the post-independence period. Therefore, educational and vocational programs abroad were embraced as an opportunity to travel. The notion of the GDR as the Promised Land for foreign students is vividly described by the former Mozambican contract worker Ibraimo, who in his autobiographical record

these dichotomies. However, a literal interpretation is possible as well. "Coconut and Bitter Tea" might then refer to Dora's work with university students on coconut and tea plantations, which is described at length. Besides, we interpret that the main story behind the "bitter tea" was that usually staff and students got black tea with sugar for breakfast in the canteen, but in times when the civil war was getting worse there was a lack of sugar, even in Maputo. Thus, the coconut could stand for the exotic part of his teaching experience and the "notion of paradise" that many Easterners associated with the deployment in the Global South, while the bitter tea could represent the hardship of the situation. The subtitle "Days and Nights in Mozambique" seems to point towards the intensity of the experience.

68 Dora, Kokos, 12

69 Dora, Kokos, 14. All quotations from memory sources were translated by Piepiorka and Buanaissa.

70 Dora, Kokos, 15. 
remembers that one day he and his fellow students found a scholarship announcement at school. The youngsters quickly decide to take their chance to go abroad and register on the application list:

We conferred with each other for a few minutes, but the dice have been cast. [...] I couldn't imagine becoming a teacher [in Mozambique]. We wanted to get out, get away from the civil war. And then there was one more thing: In the GDR white people were living. The Gods. I took a pencil out of my pocket. [...] We were ready to travel to the land of Gods. ${ }^{71}$

Interestingly enough the initially positive notions on "the other" were based upon very little actual knowledge. In some narratives the main characters initially even had difficulties to locate the respectively other country on a map. ${ }^{72}$ Preparations to fill in such knowledge gaps were organized by official authorities before embarkment, but a comparative glance suggests that training contents varied immensely in East Germany and Mozambique. Furthermore, students, teachers, blue-collar, and white-collar professionals from both countries reported that the content of their training courses did not necessarily meet the learners' needs. This can be illustrated in the recollections of Rita and Frank, who during preparatory training in the GDR were astonished that most of their Portuguese language teachers had never visited Mozambique themselves. Only one of them-upon request from the East German participants-shared some knowledge about colonial Mozambique. But his knowledge was limited to topics like architecture or general orientation in the capital city and did not cover cultural insights, which was registered by the participants with slight disappointment. ${ }^{73}$

Likewise, the Mozambican Ibraimo remembers that the training he and his fellows received did not really prepare them for what awaited them in the GDR, because it rather appeared to be a military camp than a preparations course for future workers and students. Instead of learning German vocabulary or intercultural habits, for instance, the prospective workers had to march about 40 kilometers per day. Ibraimo found this confusing, but accepted the military drill as he was convinced that it was for the sake of his future education. ${ }^{74}$ An

71 Alberto, Ich wollte leben, 77. Ibraimo's image of white people was strongly related to Portuguese colonialism. In his memory, white Portuguese acted like "Gods" who commanded over live and death in colonial Mozambique.

72 This was also the case for Frank and Ibraimo: Dora, Kokos, 13-14; Alberto, Ich wollte leben, 77.

73 Dora, Kokos, 17.

74 Alberto, Ich wollte leben, 80-81. 
East German physician confirmed to him during the application procedure that they were to study and even get interpreters until they learned German, so Ibraimo had no reason to wonder about the lack of language classes. ${ }^{75}$ Furthermore, the Mozambican instructor in the military-like camp explained that the adolescents must exercise well in order to keep up with the GDR citizens, who in his account were working from dawn to night. According to Ibraimo, "the man was serious about that, and we believed him. The foreign GDR expanded into a myth. The people living there drudged from morning to night and put themselves in the service of communism."76

Apart from this, many participants in preparatory camps did not learn anything about cultural standards. They did not read books about the GDR, and received little further orientation concerning the GDR. ${ }^{77}$ The adolescents and young adults thus discussed unverified stories "about a phenomenon called snow."78 Nevertheless, the impending departure to unknown lands filled them with great expectations and excitement. It is striking that both Mozambican and East German narrators extensively describe their travel adventures, which were accompanied by stopovers in non-socialist countries, ${ }^{79}$ or first-time flight experiences, as in the case of Ibraimo. ${ }^{80}$

\section{Unpacking Reality and Meeting "the Other"}

Another noteworthy aspect in Mozambican and East German memory texts is the way in which authors deal with realities shortly after arrival. In sections devoted to arrival, narrators deliberately integrate positive, ambivalent, and negative experiences made upon arrival into their overall storytelling. Mozambican narrators, for instance, reflected on the imbalances between their prior imaginaries and the irritating East German realities found upon arrival. East German narrators, on the other hand, rather focused on the exotic nature of the land and the

75 Alberto, Ich wollte leben, 86.

76 Alberto, Ich wollte leben, $80-81$.

77 In biographical interviews, many Mozambican worker trainees stated that information on the GDR was "gathered through hearsay and rumors." Furthermore, prospective migrants rather relied on the "experiences of friends and family members" than on official written sources while planning their stay in the GDR; see Marcia C. Schenck, "From Luanda and Maputo to Berlin," 209.

78 Ibid.

79 Dora, Kokos, 19-21.

80 Alberto, Ich wollte leben, 100. 
overall "newness" of the arrival situation, while postponing critical thoughts to later sections of their narrative.

To illustrate some critical moments of arrival in the GDR, we borrow memories from António, a Mozambican student of economy in der GDR. António remembers the adjustment to the new climate and food customs but considers such adjustments as minor problem. What really discomforted him though was the lack of contact to German locals. As he has previously got to know GDR citizens in Mozambique, he hoped to find "the same sort of people" in the GDR itself. But to his disappointment the East German residents were not as "open and sociable" as their compatriots working in Mozambique. António describes a "certain distance" that GDR citizens displayed in social interactions, which deeply puzzled him. ${ }^{81}$ Gabriel, a Mozambican teacher at the School of Friendship in Staßfurt, even remembers false allegations against Mozambicans and shares a memory that reveals racist prejudice and a notion of envy for material goods on part of East German locals: "In a youth fashion store there were merely 100 pairs of jeans on offer. Five Mozambican pupils were also queueing there, and maybe two of them bought jeans. But as we were black, we attracted attention, so in the end people would say 'The blacks again bought out everything'. And this again led to tensions." 82 In search for explanation, Gabriel concludes that probably the local people were overwhelmed with receiving 900 foreigners at once in a small place like Staßfurt. ${ }^{83}$

On the other hand, many books contain positive memories of first encounters with GDR citizens. The Mozambican adolescent Eusébio, for instance, was delegated to the GDR in the 1980s to work as a translator in East German engine plants, where Mozambican citizens received vocational training or were employed as contract workers. ${ }^{84}$ Eusébio recalls some "sympathetic Germans" willing to take care of newly arrived Mozambicans. In his view, "some of them hung out with us out of curiosity to meet a black person for the first time; others wished to find out more about our culture." ${ }^{85}$ Eusébio arrived in the GDR in Decem-

81 Renate Gudat and Abdul Ilal, "Erfahrungen von mosambikanischen Studenten in der DDR: Interviews," in Engagiert für Afrika: Die DDR und Afrika II, ed. Ulrich van der Heyden, Ilona Schleicher, and Hans-Georg Schleicher (Münster: Lit, 1994), 222, 224.

82 Gudat and Ilal, "Erfahrungen," 217.

83 For discussion of racism against non-white East German citizens, see Anna Ransiek, "Anders-Sein in der DDR - Narrative Bezüge nach der Transformation,” in Ostdeutsche Erinnerungsdiskurse nach 1989: Narrative kultureller Identität, ed. Elisa Goudin-Steinmann and Carola Hähnel-Mesnard (Berlin: Frank \& Timme Verlag, 2013).

84 Eusébio João Dembe, “Os privilegiados da década 80," in Moçambique-Alemanha, Ida e volta / Mosambik-Deutschland, Hin und zurück, ed. ICMA (Maputo: ICMA, 2005).

85 Dembe, "Os privilegiados," 65. 
ber, and while playing in the snow, he made his first contacts with fellow East German teenagers, who taught him how to ride a sledge. In return he taught a German friend to dance "a dance from Africa."86

A generally positive memory landscape was outlined by Dieter, an East German exchange student at Eduardo Mondlane University in Maputo. Dieter's narrative stresses a high spirit of camaraderie on the part of his Mozambican fellow students, who helped him to integrate in the academic life after arrival. Dieter recalls that together they organized excursions to nearby beaches and various parties. In Dieter's memory, everyone enjoyed the pleasures of the weekend and only occasional quarrels disturbed the overall friendly atmosphere in the Mozambican student dorm. However, not all GDR citizens in Mozambique had this kind of contact with locals, and Dieter even remembers notions of envy from fellow GDR citizens in this regard. ${ }^{87}$

The arrival situation was rather different for East German cooperators who traveled to Mozambique as contracted personnel. On arrival at Eduardo Mondlane University, Frank and Rita were welcomed to the university's guesthouse, where they spend three months, before receiving an apartment for the rest of their stay in Mozambique. In their remembrance, the basic conditions such as water, light, and necessary utensils for everyday life were minimally provided. ${ }^{88}$ But what seemed more exciting for them was meeting their neighbors from the Netherlands, France, Russia, or Portugal, who also worked as international cooperators at the university and shared the guesthouse with them. ${ }^{89}$ Therefore, the first sensation of meeting "the other" in the case of Frank was rather related to observing other international cooperators than to meeting his Mozambican colleagues. ${ }^{90}$ It is interesting, for instance, that Frank's description tends to exoticize his French neighbors in terms of sensuality. ${ }^{91}$ Beyond the university's guesthouse, the environment of Maputo is described at length as being beautiful and exotic. First contacts with the local population occurred during a long walk

86 Dembe, "Os privilegiados," 65.

87 Dieter Hebestreit, "Als DDR-Student in Mosambik," in Engagiert für Afrika: Die DDR und Afrika II, ed. Ulrich von der Heyden, Ilona Schleicher, and Hans-Georg Schleicher (Münster: Lit, 1994), 227-228.

88 Dora, Kokos, 23.

89 International cooperators from various countries were contracted in the Mozambican education sector in the 1970s and 1980s. FRELIMO's international recruitment strategy, in the first place, served to substitute the Portuguese professionals who left Mozambique shortly after independence, but also aimed at a quick qualification of national cadres by these international cooperators.

90 Dora, Kokos, 29, 34-35.

91 Dora, Kokos, 35. 
through the city, while Frank and his wife explored the streets of Maputo and constantly got lost. Since after independence most street names had been changed, they needed to ask locals for directions, because their city map proved to be outdated. Indeed, Maputo's streets were renamed after prominent figures of socialism such as Karl Marx, Vladimir Lenin, or Mao Tse Tung. Such personalities should have sounded familiar to Frank and Rita. In practice, however, they needed a while to get used to the Mozambican pronunciation of Friedrich Engels as "Federico Enschles," until they understood which path to follow. ${ }^{92}$

Overall it seems that former GDR cooperators' expectations were exceeded during their first weeks in Mozambique, because all East German narrators describe the beauty of nature and friendliness of people at length. An impressive example is delivered by Hans, a GDR advisor who worked at the teacher training institute in Maputo during the 1980s. Hans devotes a generous amount of text to his non-work activities in Mozambique and personal highlights like seeing a turtle, a dolphin, or a shark for the first time in his life (interestingly enough, Hans was responsible for the training of Mozambican biology teachers, amongst other duties). ${ }^{93}$ His first encounter with the Indian Ocean in particular "seemed like paradise" to him and his wife. ${ }^{94}$

\section{Solidarity as Motive in International Cooperation in Education}

Solidarity was the official motive for cooperation in education between the GDR and the PRM in the 1970s and 1980s. ${ }^{95}$ But how did this somewhat overused term manifest in the practice of everyday cooperation? In the memory books we found a rather high spirit of solidarity in travelers from both sides. But it seems that East Germans interpreted their stay in Mozambique in connection to tasks like an "internationalist duty" ${ }^{96}$ or spreading Marxist ideals, while Mozambicans re-

92 Dora, Kokos, 26-27.

93 Hans Bruchsteiner, "Vom Lernen und Lehren - als Berater in der mosambikanischen Volksbildung," in Wir haben Spuren hinterlassen! Die DDR in Mosambik: Erlebnisse, Erfahrungen und Erkenntnisse aus drei Jahrzehnten, ed. Matthias Voß (Münster: Lit, 2005), 444-448.

94 Bruchsteiner, "Vom Lernen," 445.

95 Alexandra Piepiorka, "Exploring 'Socialist Solidarity’ in Higher Education: East German Advisors in Post-Independence Mozambique (1975-1992)," in Education and Development in Colonial and Postcolonial Africa: Policies, Paradigms, and Entanglements, 1980s-1980s, ed. Damiano Matasci et al. (Cham: Palgrave Macmillan, 2020), doi:10.1007/978-3-030-27801-4_11.

96 Rainer Grajek, Berichte aus dem Morgengrauen: Als Entwicklungshelfer der DDR in Mosambik (Grimma: Ute Vallentin, 2005), 51. For further information on Grajek's deployment in Mozambique see also Katrin Bahr in this volume. 
ferred to goals like building the nation state when explicating their educational missions in the GDR. Besides the slight difference in the long-term goal formulation, it seems that solidarity in practical terms was understood as loyalty and friendship. This may be exemplified by the narrative of East German journalist Peter Spaček, ${ }^{97}$ who accompanied a FRELIMO commander on a rally to a village in Central Mozambique shortly after independence. Although the villagers never experienced contact to FRELIMO members before, Peter recalls that thousands had gathered to hear the announcements. The journalist intended to observe the meeting from the background, but the FRELIMO commander asked him to come on stage and included the foreigner into his speech:

'This comrade fought for us,' he said. Some of the listeners laughed. A white person? The audience busted out laughing as he grabbed and raised my pen. 'And this is his weapon.' But then he raised a Kalashnikov and pointed towards a nearby tree. 'With this weapon I can shoot as far as there. But with this one,' now again pointing at the pen, 'this comrade can reach out to the world. ${ }^{98}$

In his further speech, the FRELIMO commander established a connection between the author's pen and the solidarity services of socialist countries to Mozambique, stressing the education of Mozambicans in the GDR, amongst others.

Over time, this heroic notion of solidarity, which was connected with the liberation struggle and also with the general reputation of the GDR, diminished in Mozambique. This, in part, happened due to rather bureaucratic shortcomings during the actual post-independence collaboration between the two countries. This may be demonstrated using the example of the East German cooperator Udo, who was delegated to the statistical office of Mozambique in 1979, where he helped organizing countrywide censuses and supported his counterparts and trainees in statistical planning and evaluation. His supervisor did express his satisfaction with Udo's work on several occasions and wished to prolong the cooperator's contract. Nevertheless, it seems that GDR authorities were not

97 Peter Spaček was the first East German press correspondent, who visited the FRELIMO during the struggle for Mozambican independence. Already in 1970 he accompanied FRELIMOtroops into "the bush" and interviewed Samora Machel as well as other high-ranking FRELIMO-members. He published a positive report on his voyage to the FRELIMO-run "liberated areas" of Northern Mozambique in the international press and made FRELIMO's struggle known to a wider public; Peter Spaček, War ich wirklich in Moçambique? Als DDR-Korrespondent auf vier Kontinenten (Berlin: Edition Weisse Seiten, 2005), 100 - 103. For medial representation of Mozambique and FRELIMO in the GDR see also Bodie in this volume.

98 Spaček, War ich wirklich, 123-124. 
willing to let Udo go for any longer than a few months. ${ }^{99}$ Due to his only shortterm contracts, Udo used to travel back and forth between the GDR and Mozambique for five years, very much to the dismay of his Mozambican supervisor Rodrigues. After writing several requests for prolonging Udo's contract, Rodrigues eventually received a negative or only partly approving response from GDR authorities. Instead of Udo another East German cooperator was chosen to take over the job - a person who, in Rodrigues' view, did not possess the necessary skills to support the bureau's work during the next census. Resignedly, he turned to Udo: "Alas! No one makes life as hard for us as the countries we are friends with!" 100 And further he complained: "From other countries [...] people come voluntarily, with goodwill and ready to help us. With you we do have a friendship agreement, but every time there is a huge struggle to receive the requested support." ${ }^{101}$ Such dialogues between the protagonist Udo and his Mozambican counterparts point towards a trust-based communication style between the colleagues. At the same time, the practical limits of state-organized socialist solidarity are addressed quite frankly here.

\section{Learning to Understand Each Other}

Intercultural or local learning can be traced back by small episodes told in the memory books of East German cooperantes (cooperators) in Mozambique. One such episode is recalled by Rainer, a history and arts teacher who worked as advisor in the department for teacher training for the Mozambican Ministry of Education between 1981 and 1986. On one occasion, Rainer is invited by a Mozambican colleague to meet some local artists and to visit the Núcleo de Arte, Mozambique's first art association. Among other works they discuss a painting showing a curandeira (healer), a traditional medicine woman performing a healing ritual. While examining the painting, Rainer wonders why the persons lying at the feet of the curandeira opened their mouths. The artist Mankeu explains that "their illness had made them sad. Sadness seals the mouth. The open mouth therefore symbolizes that sadness has escaped."102 Deeply impressed by the African artwork, Rainer concludes in his book that this artist was like an embodiment of the Mozambican people.

99 Udo Heiland, Unter Moçambicanern: Arbeit - Leben - Abenteuer 1979 bis 1985 (Leipzig: Engelsdorfer Verlag, 2011), 320.

100 Heiland, Unter Moçambicanern, 309.

101 Heiland, Unter Moçambicanern, 349.

102 Grajek, Berichte, 257. 
But intercultural learning also occurred in the context of work - sometimes even in a classroom setting. During a practical lesson, one of Rainer's pupils, a future instructor of Marxism-Leninism named Senhor V., covered the October Revolution in Russia. Apparently, the term Bolsheviks was not familiar to all of his audience, so upon request Senhor V. explained: "You know, here in the South [of Mozambique] we have the Ronga tribe. Many Ronga are workers, peasants, or soldiers. Likewise, back then in Russia there was a tribe called Bolsheviks; many of them were also workers, peasants, soldiers." ${ }^{103}$ We strongly assume that the East German instructors of Marxism-Leninism must have disagreed with this interpretation. Despite the misinterpretation of the historical role of the Bolsheviks in Russia, the topic was not discussed further in Rainer's recollection. Nevertheless, it seems surprising that Senhor V. relied on the tribe as a figurative example to illustrate the role of the Bolsheviks in Russia, because the example contradicted FRELIMO's discourse against tribalism in Mozambican society to a large extent. Apparently, while FRELIMO's politics aimed at overcoming tribal bonds on the national level, in a small teacher training institute in Nampula the tribe served as useful reference to interpret the role of Marxist-Leninist parties in revolutionary processes, by simply picturing them as leading tribes with many workers, peasants, and soldiers. This rather creative interpretation of "a tribe called Bolsheviks" by a future Mozambican instructor of Marxism-Leninism may serve as a good example of the ideological entanglements between Africa and the East, as it shows how local actors reclaimed the historiography of socialism by adapting it to local meanings.

\section{Learning to Deal with Contradictions and Disappointments in State Socialism}

Mozambicans who lived in the GDR often express mixed feelings when they reflect on East German state socialism in their narratives. Apparently, the self-representation of the country did not resonate with everyday life as experienced by foreigners. All Mozambican narrators did experience xenophobia or racism at some point, although the GDR government claimed that the East German society was guided by anti-racist ideals. Thus, racism rarely occurred in the workplace of the Mozambican migrants, but racist assaults often occurred in spheres where state control tended to be absent, namely in bars or discotheques. ${ }^{104}$ In order

103 Grajek, Berichte, 80.

104 See Machava, this volume. 
not to hurt the comfort of the GDR population and its leadership, the Mozambican teacher Gabriel learned to control what should and should not be said. In other words, he learned to control and manage his silence. He further mentioned that in the beginning his motivation for maintaining silence was not to hurt his East German hosts. But with time he learned that "the things that were not being said, turned out to be the most important ones, in a way." 105 Regarding the issue of freedom of expression in East German state socialism, Gabriel recollects that after a while he understood the informal rules of political communication: "There were things that you would say in a private setting. There you could express your opinion, discuss with people and express criticism. And then, there were official settings, where you would say the things which were expected to be said." ${ }^{106}$ In this example, Mozambican narrators clearly work out the contradiction between the democratic self-representation of the GDR and the rather undemocratic practice of silencing political debates among citizens - or in this case foreigners. At the same time, Gabriel's memory demonstrates how foreigners adopted certain cultural practices that were common among GDR citizens.

East German observers also take up the topic of contradictions with state socialism when narrating about their experience in Mozambique. On the one hand, they recall situations in which they disagreed with the behavior of fellow GDR cooperators in Mozambique, and on the other hand, they observe contradictions in Mozambican state socialism as another noteworthy phenomenon. This may be illustrated by the autobiography of Udo, who was contracted by the Mozambican government to work on the population census and to qualify Mozambican statisticians. He and his intern from Eduardo Mondlane University were analyzing statistical data on Mozambique's industry sector from the years 1979 and 1980. A German cooperator called Micha shared the office with them, but did not show very much passion for this work. In Udo's recollections Micha affirmed that his contract was only valid for two years and that he would not stay in Mozambique for a single day longer, a stance that differed greatly from the official motive of internationalist solidarity as propagated in the GDR. Apart from that, this colleague used to speak German with Udo on all occasions, although it was obvious that none of their Mozambican colleagues would understand any German. As Udo recalled, this behavior was at least impolite if not highly offensive to their Mozambican colleagues, and Micha's attitude embarrassed him. Udo re-

105 Gudat and Ilal, "Erfahrungen,” 218.

106 Gudat and Ilal, "Erfahrungen,” 219. 
counts that many other cooperators from the GDR behaved likewise and that the Mozambican partners repeatedly complained about such behavior. ${ }^{107}$

On the other hand, GDR citizens were sometimes overwhelmed by the challenges that awaited them at their workplace. The East German educational advisor Rainer, for instance, was delegated to contribute to the history curriculum for the teacher training institutes in the country. The "expert group" in charge of curriculum planning consisted of international educators, amongst others from Brazil and Portugal, ${ }^{108}$ which led Rainer to speculate about their unwillingness to collaborate with him. Although "good sounding terms like 'socialist Mozambique', 'scientificity', and 'historical materialism'” were dropped by his international colleagues during team meetings, Rainer's version of socialist awareness was rather ignored in the curriculum planning process itself ${ }^{109}$ : "You know, Mr. Grajek, we are all from different countries - we all have very different perceptions of the term awareness." 110 Facing such statements Rainer had to leave the final decision to their Mozambican supervisor, who-in this case-chose to opt in favor of Rainer's concept of "socialist awareness." 111

What astonished East German authors was the contrast between the official appraisal of the Soviet Union as the mother state of socialism, and a seemingly minor popularity of Soviet cooperators among the Mozambican population. The East German statistician Udo remembers that during a visit to a fishermen's village at the Niassa Lake local women were uncertain if he would like to join them for lunch. Puzzled about their uncertainty, Udo asks for the reason of the women's concern and gets an upfront answer: a few weeks before his visit some "soviéticos" (Soviets) passed by the place to evaluate if a village cooperative could be founded there. The Soviet visitors chose to bring cans of tinned food instead of enjoying local food and did not cook together with the villagers. The latter concluded from this behavior that the soviéticos might have feared for their health, because they even brought water with them. Udo retrospectively regards such behavior as highly counterproductive to socialist goals like solidarity and friendship: "You cannot convince people with propaganda and beautiful

107 Heiland, Unter Moçambicanern, 74.

108 It was not unusual that international cooperators from Western countries and the Eastern bloc had to work together within the Mozambican education system. As a common language facilitated communication with Portuguese and Brazilian citizens, the Mozambican government frequently employed educational experts from both countries. See Piepiorka, "Exploring Socialist Solidarity," 290, 297.

109 Grajek, Berichte, 70.

110 Ibid.

111 Grajek, Berichte, 71. 
speeches alone. How do they want to agitate for friendship, when they isolate themselves like that? It's a mystery to me."112

In addition to critically observing the behavior of Soviet cooperators, Mozambicans frequently mentioned national problems when talking to their East German colleagues and friends. Independence has raised great hopes among the Mozambican population and socialism was officially praised as the sure road to national development. But with the growing economic crisis and an ongoing civil war during the 1980s a severe lack of goods and services became manifest. In spite of this dramatic setting, East German cooperators occasionally observed a rather elitist or even selfish behavior on part of some FRELIMO party cadres, which did not correspond to the official agenda of socialism for the ordinary people. One of such unpleasant memories is mentioned by young journalist Peter Spaček, who recounts a meeting with an old FRELIMO friend "from the bush" (meaning the armed struggle). ${ }^{113}$ Meanwhile his friend turned governor in the province capital of Tete invited Spaček for an opulent dinner. To Spaček's astonishment the new governor had taken over the former Portuguese governor's estate, including the butler. But what really caught the journalist's attention were the delicious prawns on his old friend's dining table. Such fancy foods were almost unavailable on the coast itself, but the dinner took place 400 kilometers inland and the governor apparently did not mind flying them in. He even boasted of the "solidarity" between governors that allowed him to organize such extravagances. ${ }^{114}$ Downhearted Spaček came to the conclusion that it was not worth appealing to his old friend's socialist ideals from the guerilla times: "As the idea failed in our own homes in Europe, why should it work exactly here, in faraway Africa?"115

When it came to consumer goods, some East German cooperators also observed a comparable decline in socialist ideals in the ranks of their own higher-ranking SED cadres. For instance, the biochemistry lecturer Holger, who worked at Eduardo Mondlane University, recalls an opulent reception in Maputo organized for a high-ranking SED delegation during their visit to the fifth FRELIMO Congress in 1989. What caught his attention at this reception were the boring speeches as well as the Western drinks, namely bottles of Evian water and the

112 Heiland, Unter Moçambicanern, 277.

113 Spaček has visited FRELIMO-controlled areas during the independence struggle and got to know many FRELIMO-leaders, who at that time were guerilla fighters and lived in rather spartan conditions. Thus, the post-independence luxurious lifestyle of former comrades "from the bush" may have strongly contrasted with his earlier experience with FRELIMO-officials.

114 Spaček, War ich wirklich, 153.

115 Ibid. 
soft drink Fanta on the tables. Later he learned from a colleague that these and many other Western products had been flown in especially for this government delegation and that the official airline of the GDR, Interflug, was responsible for the transport. ${ }^{116}$ Although such memory details may seem insignificant, they show very well the awareness of privilege in both socialist societies, because the privileged access to scarce or exceptional goods was often tied to higher ranks in the state apparatus. Thus, while Mozambican governors and East German government representatives may have enjoyed fancy drinks and prawns every now and then, the ordinary people (including the authors of the memory sources) were rather used to queuing for basic goods like meat or even water ${ }^{117}$ in times of shortage.

Such contradictions within state-socialist societies may be summed up in a political joke told by Mozambicans to their East German colleague during an annual works outing. The joke reads as follows: two Mozambicans want to eat fish. In the whole city they cannot get any, so they decide to go fishing at the river. After a while they catch a fair-sized fish and get out a pan to fry it. "I don't have oil," says one of them. "Well, me neither," comments the other, "so, let's fry it without oil! But I don't have any matches.” The first is disappointed: "I also don't have any. Man, let's just throw the fish back into the water." In this moment the fish turn up his head and shouts: "Viva a FRELIMO!" - Long live FRELIMO. ${ }^{118}$ In the 1980s, disillusionment about the ongoing economic crisis and the connected lack of consumer goods became widespread even among party cadres, who indeed found themselves in a relatively privileged situation within the distribution system of the FRELIMO-led state. Among the less privileged parts of the Mozambican population the "popular jokes in Maputo became increasingly bitter about the deteriorating situation."

Although the joke blatantly made fun of the government's failure to provide the Mozambican population with basic supplies, all those present join in a hearty laugh. ${ }^{120}$ The fact that this political joke was told in front of the East German colleague points to a relationship of trust, because the state censorship did

116 Holger Hegewald, "Berlin, Maputo, und zurück - Dozent an der Eduardo-Mondlane-Universität 1989-1990," in Engagiert für Afrika: Die DDR und Afrika II, ed. Ulrich van der Heyden, Illona Schleicher, and Hans-Georg Schleicher (Münster: Lit, 1994), 472- 473.

117 Dora, Kokos, 34, 54-55, also 158-159. In Dora's novel Frank's wife Rita used to queue for meat and other groceries in line with other inhabitants of Maputo city.

118 Heiland, Unter Moçambicanern, 305.

119 Jason Sumich, The Middle Class in Mozambique: The State and the Politics of Transformation in Southern Africa (Cambridge: Cambridge University Press, 2018), 86.

120 Heiland, Unter Moçambicanern, 305. 
not joke with unpleasant anecdotists - neither in the GDR nor in Mozambique. ${ }^{121}$ At the same time, it is remarkable that all the protagonists on site immediately understood the joke and the underlying humor, which points to a common understanding of the poor condition in party-led economies. Jokes with a similar undertone were also popular in the GDR and other Eastern bloc countries. ${ }^{122}$ Such anecdotes served as an outlet for annoyed or disappointed citizens in socialist societies around the globe who were promised prosperous socialist development but who at the same time regularly experienced a shortage of basic consumer goods. The circumstance that ordinary people-living in nominally people-led economies-suffered from the lack of basic supplies like matches or oil found expression in a particular genre of humor, the "communist joke". ${ }^{123}$ These jokes illustrate a common horizon of dealing with scarcity in socialist societies and the experience of addressing it ironically or subversively.

\section{Concluding Remarks}

After recapitulating selected aspects of East German and Mozambican memory literature, we wonder whether it is reasonable to speak about a transnational memory space between these two formerly socialist populations. Although memories on overall socialist realities seem to coincide in Mozambican and East German narrations about "the other", the personal realities of the narrators and their memories vary considerably. Generally speaking, East German realities seem somewhat privileged as compared to the Mozambican storytelling. This may result from the positions narrators occupied in the overall system of educational exchange between the GDR and the PRM. Most East German narrators came to Mozambique as educators or advisors. Only one East German narrator

121 For the surveillance of political jokes within the GDR see Bodo Müller, Lachen gegen die Ohnmacht: DDR-Witze im Visier der Stasi (Berlin: Ch. Links, 2016). For the context of Mozambique see Richard D. Lewis, Humor Across Frontiers, Or, Round the World in 80 Jokes (Warnford: Transcreen Publishing, 2005), 100.

122 For instance, in the GDR, the lack of certain goods manifested itself in the form of long queues that formed in front of shops that were said to have the desired goods. Nevertheless, the supply of goods often did not meet the needs of East German consumers or ran out before everyone in the queue was served. A joke dealing with the routine of rumors about queuing for consumer goods reads as follows: One housewife says to another: "I hear there'll be snow tomorrow!”, to which the other one replies: "Well, I'm not queuing for that”; see Ben Lewis, Hammer And Tickle: A History of Communism Told Through Communist Jokes (London: Phoenix, 2009), 132.

123 See Lewis, Hammer And Tickle, 11-21. 
came to Maputo for study purposes, namely to learn the Portuguese language. On the other hand, most Mozambican narrators came to the GDR as prospective students or trainees. This implies that the divergent positions of the East Germans and Mozambicans in their destination countries may have resulted in very different memories, and a rather divided memory space.

At the same time, it seems that regardless of their position within the system, all narrators picture themselves as learners in a very broad sense. Both Mozambican and East German authors tell stories about encounters with new habits, new rules, new socialist realities abroad. And many passages are devoted to the intercultural understanding of one another, resulting in new socialist entanglements. Furthermore, socialist ideals seem to be valued in both Mozambican and East German memory texts. A common tone is also palpable in passages that criticize the negative aspects of state socialism in the respectively other country. In sum, a nostalgic but ambivalent consensus on the socialist project in both countries seems to manifest in the written testimonies of its former protagonists. In that sense, we found a notion of "sharedness" in post-socialist memories that originated in very different geographical and temporal spaces, expressed through temporary moorings. As a result, we see a delightful mosaic of Euro-African storytelling on educational exchange under socialist conditions, assembled by "Mozambican-Ossis"124 (Mozambican "Easterners") and muzunguMozambicans (foreign Mozambicans). This post-socialist memory mosaic naturally remains open to further interpretation. ${ }^{125}$

\section{Bibliography}

\section{Memory Sources}

Alberto, Ibraimo. Ich wollte leben wie die Götter: Was in Deutschland aus meinen afrikanischen Träumen wurde. Köln: Kiepenheuer \& Witsch, 2014.

Bruchsteiner, Hans. "Vom Lernen und Lehren - als Berater in der mosambikanischen Volksbildung." In Wir haben Spuren hinterlassen! Die DDR in Mosambik: Erlebnisse, Erfahrungen und Erkenntnisse aus drei Jahrzehnten, edited by Matthias Voß, 434-462. Münster: Lit, 2005.

124 Grajek, Berichte, 268. Depending on the context, “Ossi” may be a colloquial or pejorative term for a person originating from Eastern Germany (or the former GDR).

125 We want to send a cordial obrigado and Danke to Anne Dietrich and Marcia C. Schenck, who accompanied us in our journey through post-socialist memory landscapes with incredible patience and invaluable advice in the process of writing. 
Dembe, Eusébio João. "Os privilegiados da década 80." In Moçambique-Alemanha, ida e volta: vivências dos Moçambicanos antes, durante e depois da estadia na Alemanha / Mosambik-Deutschland, hin und zurück: Erlebnisse von Mosambikanern vor, während und nach dem Aufenthalt in Deutschland, edited by ICMA, 63-70. Maputo: ICMA, 2005.

Dora, Helmut. Kokos und bitterer Tee: Tage und Nächte in Mosambik. Rostock: BS-Verlag, 2009.

Grajek, Rainer. Berichte aus dem Morgengrauen: Als Entwicklungshelfer der DDR in Mosambik. Grimma: Ute Vallentin, 2005.

Gudat, Renate, and Abdul Ilal. "Erfahrungen von mosambikanischen Studenten in der DDR: Interviews." In Engagiert für Afrika. Die DDR und Afrika II, edited by Ulrich van der Heyden, Illona Schleicher, and Hans-Georg Schleicher, 215-225. Münster: Lit, 1994.

Hebestreit, Dieter. "Als DDR-Student in Mosambik." In Engagiert für Afrika: Die DDR und Afrika II, edited by Ulrich van der Heyden, Illona Schleicher, and Hans-Georg Schleicher, 226-229. Münster: Lit, 1994.

Hegewald, Holger. "Berlin, Maputo, und zurück - Dozent an der Eduardo-Mondlane-Universität 1989-1990.” In Engagiert für Afrika: Die DDR und Afrika II, edited by Ulrich van der Heyden, Illona Schleicher, and Hans-Georg Schleicher, 463-480. Münster: Lit, 1994.

Heiland, Udo. Unter Moçambicanern: Arbeit - Leben - Abenteuer 1979 bis 1985. Leipzig: Engelsdorfer Verlag, 2011.

Spaček, Peter. War ich wirklich in Moçambique? Als DDR-Korrespondent auf vier Kontinenten. Berlin: Edition Weisse Seiten, 2005.

\section{Secondary Literature}

Achille, Etienne, Charles Forsdick, and Lydie Moudileno, eds. Postcolonial Realms of Memory: Sites and Symbols in Modern France. Liverpool: Liverpool University Press, 2020.

Assmann, Aleida. Erinnerungsräume: Formen und Wandlungen des kulturellen Gedächtnisses. Munich: C.H. Beck, 1999.

Aleida Assmann. "Memory, Individual and Collective." In The Oxford Handbook of Contextual Political Analysis, edited by Robert E. Goodin and Charles Tilly, 210-224. Oxford: Oxford University Press, 2006.

Assmann, Aleida. "Wem gehört Geschichte? Fakten und Fiktion in der neueren deutschen Erinnerungsliteratur." Internationales Archiv für Sozialgeschichte der deutschen Literatur 36 (2011): 213-225.

Blaschke, Bernd. "Erzählte Gefühle und Emotionen des Erinnerns: Ostdeutsche Identitätsliteratur der in den 1960er und 1970er Jahren Geborenen.” In Ostdeutsche Erinnerungsdiskurse nach 1989: Narrative kultureller Identität, edited by Elisa Goudin-Steinmann and Carola Hähnel-Mesnard, 245-263. Berlin: Frank \& Timme, 2013.

Cesari, Chiara de, and Ann Rigney, eds. Transnational Memory: Circulation, Articulation, Scales. Berlin: De Gruyter, 2014.

Coelho, João Paulo Borges. "Politics and Contemporary History in Mozambique: A Set of Epistemological Notes." Kronos 39 (2013): 20-31. 
Creet, Julia. "Introduction: The Migration of Memory and Memories of Migration." In Memory and Migration: Multidisciplinary Approaches to Memory Studies, edited by Julia Creet and Andreas Kitzmann, 3-26. Toronto: University of Toronto Press, 2011.

Creet, Julia, and Andreas Kitzmann, eds. Memory and Migration: Multidisciplinary Approaches to Memory Studies. Toronto: University of Toronto Press, 2011.

Criser, Regine. "Zwischen Anpassung und Instrumentalisierung: Hybride Lebensnarrative in der Literatur nach 1989." In Ostdeutsche Erinnerungsdiskurse nach 1989: Narrative kultureller Identität, edited by Elisa Goudin-Steinmann and Carola Hähnel-Mesnard, 199-212. Berlin: Frank \& Timme, 2013.

Cross, Michael. An Unfulfilled Promise: Transforming Schools in Mozambique. Addis Ababa: OSSREA, 2011.

den Boer, Pim, ed. Europäische Erinnerungsorte: Europa und die Welt. 3 vols. 3. Munich: Oldenbourg, 2012.

Eigler, Friederike. Gedächtnis und Geschichte in Generationenromanen seit der Wende. Berlin: Erich Schmidt, 2005.

Erll, Astrid. “Travelling Memory." Parallax 17 (2011): 4-18. Accessed January 31, 2020. doi:10.1080/13534645.2011.605570.

Erll, Astrid. Kollektives Gedächtnis und Erinnerungskulturen: Eine Einführung. 3rd ed. Stuttgart: J.B. Metzler, 2017.

Fonseca, Ana Margarida. "(Re)Configurations of Identity: Memory and Creation in the Narrative of Mia Couto." In Mozambique on the Move: Challenges and Reflections, edited by Sheila P. Khan, Maria P. Meneses, and Bjørn E. Bertelsen, 135-152. Leiden, Boston: Brill, 2018.

François, Etienne, and Hagen Schulze, eds. Deutsche Erinnerungsorte - Eine Auswahl. Munich: C. H. Beck, 2005.

Geissler, Gert, and Ulrich Wiegmann. Schule und Erziehung in der DDR: Studien und Dokumente. Neuwied: Hermann Luchterhand, 1995.

Göschl, Regina. DDR-Alltag im Museum: Geschichtskulturelle Diskurse, Funktionen und Fallbeispiele im Vereinten Deutschland. Münster: Lit, 2019.

Graf, Herbert. "Vor der Unabhängigkeitserklärung Mosambiks - Erinnerungen und Reflexionen." In Wir haben Spuren hinterlassen! Die DDR in Mosambik: Erlebnisse, Erfahrungen und Erkenntnisse aus drei Jahrzehnten, edited by Matthias Voß, 61-129. Münster: Lit, 2005.

Grammes, Tilman, Henning Schluß, and Hans-Joachim Vogler. Staatsbürgerkunde in der DDR: Ein Dokumentenband. Wiesbaden: VS, 2006.

Gratzemann, Andreas. Die Erziehung zum “neuen” Menschen im Jugendwerkhof Torgau: Ein Beitrag zum kulturellen Gedächtnis. Münster: Lit, 2008.

Gronenthal, Mariell C. Nostalgie und Sozialismus: Emotionale Erinnerung in der deutschen und polnischen Gegenwartsliteratur. Bielefeld: Transcript, 2018.

Hahn, Hans Henning, Robert Traba, and Peter Oliver Lowe, eds. Deutsch-Polnische Erinnerungsorte. 5 vols. Paderborn: Schöningh, 2012-2015.

Halbwachs, Maurice. Das kollektive Gedächtnis. Stuttgart: Enke, 1967.

Handro, Saskia, ed. Aufarbeitung der Aufarbeitung: Die DDR im geschichtskulturellen Diskurs. Schwalbach: Wochenschau-Verlag, 2011. 
Harisch, Immanuel Rafael. "Bartering Coffee, Cocoa and W50 Trucks: The Trade Relations of the GDR, Angola and São Tomé in a Comparative Perspective." Global Histories 3 (2017): 43-60. Accessed October 31, 2019. doi:10.17169/GHSJ.2017.135.

Hodgin, Nick, and Caroline Pearce, eds. The GDR Remembered: Representations of the East German State Since 1989. Camden House: Boydell \& Brewer, 2011.

Honecker, Erich. Aus Meinem Leben. Berlin: Dietz, 1981.

Igreja, Victor. "Memories as Weapons: The Politics of Peace and Silence in Post-Civil War Mozambique." Journal of Southern African Studies 34 (2008): 539-556.

Klinge, Sebastian. 1989 und wir: Geschichtspolitik und Erinnerungskultur nach dem Mauerfall. Bielefeld: Transcript, 2015.

Kunze, Thomas, and Thomas Vogel, eds. Ostalgie international: Erinnerungen an die DDR von Nicaragua bis Vietnam. Berlin: Ch. Links, 2010.

Langa, Patricio Vitorino. Higher Education in Portuguese Speaking African Countries: A Five Country Baseline Study. Cape Town: African Minds, 2013. Accessed October 15, 2019. www.africanminds.co.za/wp-content/uploads/2014/02/AM-HE-in-Lusophone-Africa-Textand-Cover-web.pdf.

Lehnert, Gertrud. "Raum und Gefühl.” In Raum und Gefühl: Der Spatial Turn und die neue Emotionsforschung, edited by Gertrud Lehnert, 9-25. Bielefeld: Transcript, 2011.

Lewis, Richard D. Humor Across Frontiers, Or, Round the World in 80 Jokes. Warnford: Transcreen Publishing, 2005,

Lewis, Ben. Hammer and Tickle: A History of Communism Told Through Communist Jokes. London: Phoenix, 2009.

Lüdeker, Gerhard Jens. Kollektive Erinnerung und nationale Identität: Nationalsozialismus, DDR und Wiedervereinigung im deutschen Spielfilm nach 1989. Munich: Ed. Text + Kritik, 2012.

Mählert, Ulrich, ed. Die DDR als Chance: Neue Perspektive auf ein altes Thema. Berlin: Metropol, 2016.

Matasci, Damiano, Miguel Bandeira Jerónimo, and Hugo Dores, eds. Education and Development in Colonial and Postcolonial Africa: Policies, Paradigms, and Entanglements, 1980s-1980s. Cham: Palgrave Macmillan, 2020.

Millei, Zsuzsa, Iveta Silova, and Susanne Gannon. "Thinking Through Memories of Childhood in (Post)Socialist Spaces: Ordinary Lives in Extraordinary Times.” Children's Geographies (2019), 1-14. Accessed January 24, 2020. doi:10.1080/14733285.2019.1648759.

Moller, Sabine. "Diktatur und Familiengedächtnis: Anmerkungen zu Widersprüchen im Geschichtsbewusstsein von Schülern." In Aufarbeitung der Aufarbeitung: Die DDR im Geschichtskulturellen Diskurs, edited by Saskia Handro, 140-151. Schwalbach: Wochenschau-Verlag, 2011.

Mouzinho Mário, Peter Fry, Lisbeth A. Levey, and Arlindo Chilundo. Higher Education in Mozambique: A Case Study. Oxford, Maputo: James Currey; Imprensa \& Livraria Universitária UEM, 2003.

Müller, Tanja. Legacies of Socialist Solidarity: East-Germany in Mozambique. London: Lexington, 2014.

Müller, Bodo. Lachen gegen die Ohnmacht: DDR-Witze im Visier der Stasi. Berlin: Ch. Links, 2016.

Niederhut, Jens. Die Reisekader: Auswahl und Disziplinierung einer privilegierten Minderheit in der DDR. Leipzig: Evangelische Verlagsanstalt, 2005. 
Nora, Pierre, and Lawrence D. Kritzmann, eds. Realms of Memory: Rethinking the French Past. 1-3. New York: Columbia University Press, 1996-1998.

Parkes, Stuart. "Literary Portrayals of the GDR by Non-GDR Citizens." In The GDR Remembered: Representations of the East German State Since 1989, edited by Nick Hodgin and Caroline Pearce, 54-68. Camden House: Boydell \& Brewer, 2011.

Piepiorka, Alexandra. "Exploring 'Socialist Solidarity' in Higher Education: East German Advisors in Post-Independence Mozambique (1975-1992)." In Education and Development in Colonial and Postcolonial Africa: Policies, Paradigms, and Entanglements, 1980s-1980s, edited by Damiano Matasci, Miguel B. Jerónimo and Hugo Dores, 289-318. Cham: Palgrave Macmillan, 2020.

Pitcher, Anne M. "Forgetting from Above and Memory from Below: Strategies of Legitimation and Struggle in Postsocialist Mozambique." Journal of the International African Institute 76 (2006): 88-112.

Ransiek, Anna. "Anders-Sein in der DDR - Narrative Bezüge nach der Transformation." In Ostdeutsche Erinnerungsdiskurse nach 1989: Narrative kultureller Identität, edited by Elisa Goudin-Steinmann and Carola Hähnel-Mesnard, 79-95. Berlin: Frank \& Timme, 2013.

Reuter, Lutz R., and Annette Scheunpflug. Die Schule der Freundschaft: Eine Fallstudie zur Bildungszusammenarbeit zwischen der DDR und Mosambik. Münster: Waxmann, 2006.

Ritschel, Susanne. Kubanische Studierende in der DDR: Ambivalentes Erinnern zwischen Zeitzeuge und Archiv. Hildesheim: Georg Olms, 2015.

Roos, Hans-Jochen. "Unterricht unter Palmen: Als Biologielehrer an der FRELIMO-Schule in Bagamoyo." In Wir haben Spuren hinterlassen! Die DDR in Mosambik: Erlebnisse, Erfahrungen und Erkenntnisse aus drei Jahrzehnten, edited by Matthias Voß, 407-425. Münster: Lit, 2005.

Rudnick, Carola S. Die andere Hälfte der Erinnerung: Die DDR in der Deutschen Geschichtspolitik nach 1989. Bielefeld: Transcript, 2011.

Rupprecht, Tobias. Soviet Internationalism after Stalin: Interaction and Exchange between the USSR and Latin America during the Cold War. Cambridge: Cambridge University Press, 2015.

Sabrow, Martin, ed. Erinnerungsorte der DDR. Munich: C. H. Beck, 2009.

Sabrow, Martin. "Zeitgeschichte als Aufarbeitung: Der Fall DDR." In Aufarbeitung der Aufarbeitung: Die DDR im geschichtskulturellen Diskurs, edited by Saskia Handro, 21-36. Schwalbach: Wochenschau-Verlag, 2011.

Saul, John S. Revolutionary Traveller: Freeze-Frames from a Life. Winnipeg: Arbeiter Ring Publishing, 2009.

Schenck, Marcia C. "Ostalgie in Mosambik: Erinnerungen ehemaliger mosambikanischer Vertragsarbeiter in der DDR." Südlink 172 (2015): 21-23.

Schenck, Marcia C. "From Luanda and Maputo to Berlin: Uncovering Angolan and Mozambican Migrants' Motives to Move to the German Democratic Republic (1979-1990)." African Economic History 44 (2016): 202-234. Accessed February 12, 2020. doi:10.1353/aeh.2016.0008.

Schenck, Marcia C. "A Chronology of Nostalgia: Memories of Former Angolan and Mozambican Worker Trainees to East Germany." Labor History 59 (2018): 352-74. Accessed October 30, 2019. doi:10.1080/0023656X.2018.1429187. 
Schleicher, Ilona. "Berufsbildung und Wirtschaftsbeziehungen DDR - Mosambik." In Engagiert für Afrika: Die DDR und Afrika II, edited by Ulrich van der Heyden, 179-195. Münster: Lit, 1994.

Schmieder, Ulrike. "Orte des Erinnerns und Vergessens: Denkmäler, Museen und historische Schauplätze von Sklaverei und Sklavenhandel.” Comparativ 22 (2012): 60-94.

Searle, Chris. We're Building the New School: Diary of a Teacher in Mozambique. London: Zed Press, 1981.

Sengupta, Indra. "Introduction. Locating Lieux De Mémoire: A (Post)Colonial Perspective." In Memory, History, and Colonialism: Engaging with Pierre Nora in Colonial and Postcolonial Contexts, edited by Indra Sengupta, 1-8. London: German Historical Institute, 2009.

Sengupta, Indra, ed. Memory, History, and Colonialism: Engaging with Pierre Nora in Colonial and Postcolonial Contexts. London: German Historical Institute, 2009.

Siewert, Stephanie. "Die Topographie der Melancholie in transnationaler Perspektive." In Raum und Gefühl: Der Spatial Turn und die neue Emotionsforschung, edited by Gertrud Lehnert, 216-228. Bielefeld: Transcript, 2011.

Silova, Iveta, ed. Post-Socialism Is Not Dead: (Re)Reading the Global in Comparative Education. Bingley: Emerald Group Publishing, 2010.

Silova, Iveta, Nelli Piattoeva, and Zsuzsa Millei, eds. Childhood and Schooling in (Post) Socialist Societies: Memories of Everyday Life. Cham: Springer International Publishing, 2018.

Silova, Iveta, Noah W. Sobe, Alla Korzh, and Serhiy Kovalchuk, eds. Reimagining Utopias: Theory and Method for Educational Research in Post-Socialist Contexts. Rotterdam: Sense Publishers, 2017.

Sumich, Jason. The Middle Class in Mozambique: The State and the Politics of Transformation in Southern Africa. Cambridge: Cambridge University Press, 2018.

Tedesco, Maria do Carmo Ferraz. "Reconfiguração da Moçambicanidade nos romances de Mia Couto e Paulina Chiziane." Revista Mosaico 3 (2010): 81-91.

Tembe, Joel das Neves, ed. História da Luta de Libertação Nacional. Maputo: Ministério dos Combatentes, Direcção Nacional de História, 2014.

Tippner, Anja, and Anna Artwińska, eds. Narrative of Annihilation, Confinement, and Survival: Camp Literature in a Transnational Perspective. Berlin, Boston: De Gruyter, 2019.

Todorova, Maria, and Zsuzsa Gille, eds. Post-Communist Nostalgia. Oxford: Berghahn, 2010.

Traverso, Enzo. Left-Wing Melancholia: Marxism, History, and Memory. New York: Columbia University Press, 2016.

Tullner, Mathias. "Die Zusammenarbeit der DDR und Mosambiks auf dem Gebiet der Bildung und die Tätigkeit der Bildungsexperten der DDR in Mosambik." In Wir haben Spuren hinterlassen! Die DDR in Mosambik: Erlebnisse, Erfahrungen und Erkenntnisse aus drei Jahrzehnten, edited by Matthias Voß, 388-406. Münster: Lit, 2005.

van der Heyden, Ulrich, Wolfgang Semmler, and Ralf Straßburg. Mosambikanische Vertragsarbeiter in der DDR-Wirtschaft: Hintergrund - Verlauf - Folgen. Münster: Lit, 2014.

Vogel, Wolf-Dieter, and Verona Wunderlich, eds. Abenteuer DDR: Kubanerinnen und Kubaner im deutschen Sozialismus. Berlin: Karl Dietz, 2011.

Wandel, Malte. Einheit, Arbeit, Wachsamkeit: Die DDR in Mosambik. Heidelberg: Kehrer Verlag: 2012. 
Welzer, Harald. Das kommunikative Gedächtnis: Eine Theorie der Erinnerung. Munich: C. H. Beck, 2002.

Zawangoni, Salvador André. A FRELIMO e a formação do Homem Novo (1964-1974 e 1975-1982). Maputo: CIEDIMA, 2007. 
